\title{
СПЕЦИФІКА ФУНКЦІЮВАННЯ ГРАДАЦІЙНИХ СПОЛУЧНИКІВ 3 КОМПОНЕНТАМИ НЕ ТЕ ЩО, НЕ ТЕ ЩОБ
}

Стаття присвячена виявленню специфіки функціювання градаційних сполучників з компонентами не те що, не те щоб у синтаксичних конструкиіях української мови. Здійснений аналіз дає змогу стверджувати, щзо в українській мові функиіюють два парні градаційні сполучники з базовими компонентами не те що, не те щоб. У процесі аналізу було з'ясовано, що перша й друга частини иии сполучників можуть варіюватися. Установлено, що зміст фрагмента градаційного речення, який містить компоненти сполучників не те що, не те щоб, завжди відповідає критерію необхідності, а зміст іншого - критерію достатності. Використання цих сполучників у висловленні завжди зумовлене комунікативним наміром мовия.

Ключові слова: градаційне відночення, градаційні речення, комунікативний намір мовия, критерії необхідності й достатності, парні градаиійні сполучники.

Spilnyk T. Specificity of Functioning of Gradation Conjunctions with Components не те що, не те щоб. The article is devoted to revealing the specifics of functioning of gradation conjunctions with components не те що, не те щоб in the syntactic constructions of the Ukrainian language. The analysis of gradation sentences with the above mentioned conjunctions shows that in the Ukrainian language there are two paired gradational conjunctions with basic components не те що, не те щоб.

It has been found out that both the first and the second part of these conjunctions can vary. The variability of the first part of the studied conjunctions is that the forms не то що, не то щоб, не так що, не так щоб are morphological variants of the components не те що and не те щоб. The second part of the

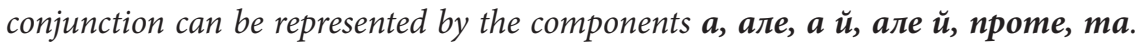
It often happens that together with the component $\boldsymbol{a}$, and sometimes instead of it, in the second part of the conjunctions such lexemes as просто, навіть, навпаки, тільки, взагалі, скоріме, сам (сама, самі), все ж, якось, вже, бодай, хай апd others can be used. The above mentioned words are not a part of the conjunction, but act as reinforcing elements, which, according to the speaker, are supposed to emphasize the unexpected informative content of the second part of the statement.

The specific feature of these conjunctions is that in simple gradation sentences the part that contains the components не те що, не те щзоб can take both the first and the second positions. In the sentences where the parts are in a reverse order, these conjunctions do not have the second part. In such situation they become singular. 
Regardless the order of the parts in a gradation sentence, the content of the part with the components of the conjunctions не те що, не те щоб, always meets the criterion of necessity, and the content of the second part of the sentence - the criterion of sufficiency. Both criteria determine the essence of gradation relationship.

It has been established that the use of the analyzed conjunctions in the utterance always results from the communicative intention of the speaker. These sentences reflect the speech activity of the speaker when he tries to use such lexical means that will help him reflect a real situation.

Key words: gradation relationship, gradation sentences, communicative intention of the speaker, criteria of necessity and sufficiency, paired gradation conjunctions.

\section{Вступ}

Синтаксичні конструкції, частини яких поєднують парні сполучники з компонентами не те що, не те щоб, у вітчизняній синтаксичній науці залишаються малодослідженими. У навчальних посібниках із синтаксису української мови, наукових розвідках, де їм приділено увагу, такі конструкції вивчають переважно в межах речень з градаційним відношенням між частинами, а сполучники зі згаданими компонентами визначають як власне градаційні (Слинько, Гуйванюк, \& Кобилянська, 1994; Городенська, 2019, Спільник, 2004; Весельська, 2014; Рула, 2018).

Попри те, що дослідники неодноразово відзначали своєрідність цих речень порівняно з іншими реченнями з градаційним відношенням, усе ж їхні погляди на такі конструкції не відзначаються однозначністю. Зокрема, аналізуючи складносурядні градаційні речення з парними сполучниками з компонентами не те що, не те щоб, К. Г. Городенська зауважує, що ці сполучники «поєднують такі дві сурядні частини, семантично значущішою із-поміж яких є перша порівняно з другою» (Городенська, 2019: 35). На думку дослідниці, такому семантичному співвідношенню сприяють лексичні значення слів, що наповнюють обидві сурядні частини.

Специфіку складносурядних речень зі сполучниками не те що...

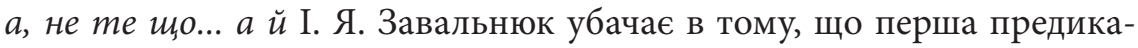
тивна частина містить мінімум інформації, тоді як друга аргументує, удокладнює контекст (Завальнюк, 2009: 204). Щодо названих сполучників, то дослідниця відзначає їхн розмовне маркування.

Схожої думки дотримується й Г. С. Весельська, зазначаючи, що використання сполучників не те що... а й, не те щоб... а й сприяє 
орозмовленню сучасної української прози та періодики (Весельська, 2014: 101). За словами авторки, ці сполучники «ще більше увиразнюють доданий компонент до попереднього, посилюючи чи послаблюючи його значення» (Весельська, 2010: 166).

Ці та інші суперечливі питання, зокрема й те, що на сьогодні немає єдиної думки щодо кількісного складу сполучників з компонентами не те щь, не те щоб, зумовлюють потребу подальшого їх дослідження й актуальність цієї розвідки.

У пропонованій статті ставимо за мету виявити специфіку функціювання градаційних сполучників з компонентами не те що, не те щцоб у синтаксичних конструкціях української мови. Досягнення поставленої мети передбачає виконання таких завдань: 1) встановити кількість градаційних парних сполучників, які містять компоненти не те що, не те щоб; 2) виявити особливості структури сполучників з компонентами не те що, не те щоб.

\section{Методи дослідження}

Методи дослідження зумовлені його метою і завданнями. У процесі аналізу матеріалу застосовано описовий, трансформаційний методи та метод зіставлення.

\section{Виклад основного матеріалу}

Градаційні сполучники загалом і парні з компонентами не те щзо, не те щоб зокрема з-поміж інших сполучників вирізняються тим, що їх використання у висловленні зумовлене комунікативним наміром мовця. Маючи на меті донести до слухача певну ідею, переконати чи вразити його, мовець і будує своє висловлення в градаційному ключі, використовуючи градаційні засоби зв'язку.

Подаючи одну частину свого висловлення як необхідну для розуміння всього повідомлення, мовець розуміє, що цієї інформації все ж таки не достатньо для задоволення його комунікативної потреби. 3 огляду на це він приєднує другу частину, зміст якої, на його думку, $€$ достатнім для того, щоб висловлення набуло довершеності.

У синтаксичних конструкціях з досліджуваними сполучниками на недостатність інформативного змісту однієї з частин указують компоненти не те що, не те щзоб, які в ній розміщені. Уживання названих компонентів і свідчить про те, що має слідувати ще одна частина конструкції, яка й надає висловленню достатності. 
Аналіз синтаксичних праць свідчить про те, що на сьогодні немає єдності в поглядах лінгвістів на кількість сполучників з досліджуваними компонентами, а також на їхній склад. Наприклад, одні вчені подають лише один сполучник не те щьоб... але (Пономарів, 1997: 310). Інші дослідники поділяють цю думку, проте відзначають варіативність компонента що в складі першої частини сполучника: не те щзо (щьоб)... але (Караман, 2011: 294). Треті вказують на те, що це два сполучники, першою частиною яких є компоненти не те щ, не те щзоб, а другою - компонент a (Слинько, Гуйванюк, \& Кобилянська, 1994: 629). Четверті дослідники погоджуються з компонентним складом першої частини сполучників (не те щ,о, не те щьоб), проте, на їхню думку, друга частина сполучників представлена компонентом $a \breve{u}$ (Весельська, 2014: 101). П’яті виокремлюють два парні сполучники, які мають однаковий компонент не те щзо в першій частині, але різні компоненти $a, a \breve{u}$ у другій: не те щзо... a, не те щзо... a й (Завальнюк, 2009: 204). Крім того, є думка, згідно з якою кількість сполучників з назва-

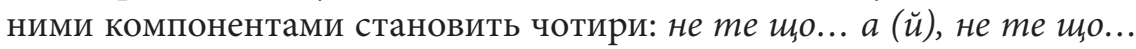

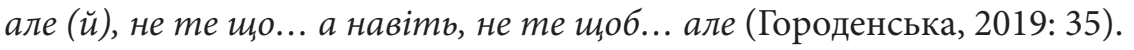

На нашу думку, є два парні сполучники з базовими компонентами не те шьо, не те щьоб у першій частині, яка складається із заперечної частки не, указівного займенника mе, який можуть заміщувати

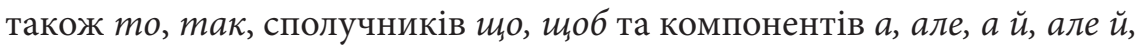
проте, mа в другій частині, наприклад: Втім, заради коханої я готовий був з йсти не те шьо папір, $\boldsymbol{a} \breve{\boldsymbol{u}}$, здавалося, залізо зубами гризти... (А. Власюк); [Заводіякою завжди найменший - Брек.] Не те шьоб чинив усе зле, але завдавав дорослим жабам клопоту ще й клопоту (В. Врублевська); [Що тут діялося - і розповісти не можна,] а в мене не то шо піджачка трикового не було вже, а, дозвольте сказати, сама сорочка на тілі... (У. Самчук); [<...> колись вони сиділи за однією партою $i<\ldots>$ ще й досі часом зустрічалися!] Не так шоб часто, але неодмінно вдавали з себе давніх приятелів... (В. Шевчук), Далі - відчула себе не те шьоб мізерною, проте меншою $і$ легшою... (Н. Шейко-Медведєва).

Особливість досліджуваних сполучників, яка вирізняє їх 3-поміж інших парних градаційних сполучників, полягає в тому, що як перша, так і друга їхні частини можуть варіюватися. Зокрема, варіативність першої частини сполучників полягає в тому, що форми не то щз, не то щьоб, не так щзо, не так щьоб є морфологічними варіантами 
не те щзо та не те щзб. Щодо другої частини цих сполучників, то разом, а іноді й замість компонента $а$ можуть бути використані такі лексеми, як просто, навіть, навпаки, тільки, взагалі, скоріше, сам (сама, самі), все ж, якось, вже, бодай, хай та ін. Видається, що ці слова не входять до складу сполучника, а лише виступають підсилювальними елементами, які, на думку мовця, допоможуть підкреслити несподіваність, неочікуваність інформативного змісту другої частини висловлення і в такий спосіб привернути увагу слухача, певним чином вразити його, наприклад: Дружина Івана Івановича, <... >, наштовхнулася на великий ящик, <...>. Не те що підняти, а просто посунути його було неможливо (А. Власюк); <...> ще ніхто не вигадав машини, яка могла 6 перестрибувати не те що п'ять кілометрів грязюки, a навіть п'ять метрів (П. Загребельний); Вона (Ірка - С.Т.) відчула дикий дискомборт: не те що ій не хотілося туди їхати, навпаки, ї туди тягло ... (М. Гримич); [- А мені довелося-таки стати відмінником. <...> - Важко, мабуть? <...>] - Не так щоб і важко, тільки дуже марудно (А. Дімаров); [Від бочманші, звісно, не приховалося, що між Дьомою і Марією пробігла якась кішка, одначе на ї̈ прискіпування дочка тільки здивовано знизувала плечима: - <..> Яка кішка?] Та між нами не те що кішка, хай олень з оленихою проскочать, $і$ то не посварять (О. Гончар).

Аналіз градаційних речень доводить, що друга частина речення, що містить лексеми просто, навпаки, часто може бути відокремленою, парцельованою, наприклад: [Він йшов звідси, коли сюди приходила перша закохана парочка.] Не те щоб його дратувало кохання. Просто він не любив отого привселюдного тримання за руки... (О. Деркачова); [ в враз мені зробилося невимовно соромно.] Не те щоб я відчув ницість моєї акторської ролі перед величчю життєвої ролі иих людей. Ні. Навпаки, [мені стало невимовно соромно тому, що саме в цю хвилину] я відчув велич моєї акторської ролі, велич моєї професії мития (Ю. Смолич). Інколи досліджувані синтаксичні конструкції можуть також уживатися без другої частини сполучників, як у реченнях: Родичі були не те що задоволені - щасливі (А. Цінцірук); Та не могла Бібігуль не те щзо розплющити своїх очей - вона не могла навіть кліпнути віями (С. Тельнюк).

Привертають увагу прості градаційні речення, у яких рівноправні частини, поєднувані досліджуваними сполучниками, слідують 
у зворотному порядку. Ідеться про те, що частина з компонентами не те щ,о, не те щзоб може займати в реченні як першу, так і другу позицію, наприклад: [У жандарма відклеївся один вус... А що ж ви хочете!] Таких випробувань справжні вуса не витримають, не те ияо приклеєні (В. Нестайко); [- А чи не можна отамана сюди покликати? <...> - Що ви! <...>] - Я боюсь глянути на нього, а не те щьоб кликати (В. Гжицький); [Фока був гордий з такої довіри, аж загорівся. Проте чи упорається він з таким дорученням?] - Ти з самим королем упораєися, не мо шзо з війтом, - сказав Довбуш (В. Гжицький). Видається, що в такому разі ці сполучники вже не є парними, оскільки не мають другої частини, а переходять до розряду одиничних сполучників.

Для градаційних конструкцій зі сполучниками, які містять компоненти не те щь, не те щьб, характерним є той факт, що, незалежно від того, де розміщена частина зі згаданими компонентами, тобто на початку чи в кінці висловлення, іiі зміст завжди є необхідним для розуміння всього повідомлення. Передуватиме ж їй частина, інформативний зміст якої $€$ достатнім для реалізації комунікативного наміру мовця. Ця особливість відрізняє їх від інших речень з градаційним відношенням, у яких спочатку розміщена необхідна інформація, а потім достатня. До того ж у разі зворотного слідування частин градаційної конструкції необхідна інформація, як правило, експліцитно представлена в попередньому контексті. Переконатися в тому, що зміст частини градаційного речення з компонентами не те шьо, не mе щьоб є завжди необхідним, а зміст іншої - достатнім, можна, помінявши частини наведених вище речень місцями, пор.: Таких випробувань не те шьо приклеєні, справжні вуса не витримають; Я боюсь не те шьоб кликати, а глянути на нього; Ти не то изо з війтом, з самим королем упораєися.

Варто відзначити також градаційні речення, у яких семантика сполучників з компонентами не те щ,о, не те щоб може бути близь-

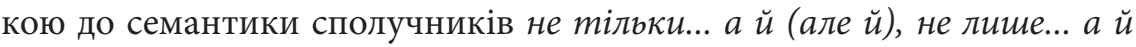
(але $\breve{u})$. Прикладами можуть слугувати такі речення: [I навіmь mодi, коли хтось із чужих чоловіків залииявся до неї (Теклі - С.Т.),] Цвігун не те шо не лаявся, а він навіть робив вигляд, щзо нічого не помічає (Є. Кравченко), пор.: Цвігун не тільки не лаявся, а він навіть робив вигляд, щуо нічого не помічає; [Шляхта і капітан позатерпали знову: не стріляти? Куди не стріляти? По чому?] Тут не те шьо стріляти, 
а вже й тримати в руках зброю не хотілося (М. Вінграновський), пор.: Тут не тільки стріляти, а вже й тримати в руках зброю не хотілося.

Однією з особливостей градаційних речень з досліджуваними сполучниками $є$ те, що їхні дві частини, у яких розміщені компоненти цих сполучників, можуть бути роз'єднані вставною конструкцією, яка містить, так би мовити, поправку до змісту першої частини, наприклад: Андрій розділив щире захоплення товариша: не те що знався на винах, він і краплини досі до рота не брав, але його заворожували романтичні ті назви, що дихали казковою Грузією (А. Дімаров); I не те щоб відчував бодай зловтішні почуття - ні, цього не було (була, сливе, легка журба), але закрадались таємні сумніви <...> (Ю. Щербак); [Приходько ж насправді почувався зле.] Не те щоб зовсім розхворівся, - такого ще з ним не бувало, він належав до тих, хто хворіє раз у житті - перед смертю, а трохи мовби морозило, трохи боліло у грудях та дерло у горлі <...> (А. Дімаров). Наявність додаткової інформації між необхідною і достатньою свідчить про труднощі мовця в процесі добору мовних засобів, що, на його думку, найбільш точно позначали 6 ситуацію реальної дійсності, а також про його прагнення скерувати увагу слухача в правильному напрямі, донести до нього сутність повідомлення.

Як можна побачити з прикладів, градаційні парні сполучники з компонентами не те що, не те щоб можуть поєднувати не лише предикативні частини складносурядних речень, а й однорідні члени в простих реченнях. Специфіка цих градаційних речень полягає в тому, що в них відображено мовленнєву діяльність мовця з пошуку тих лексичних засобів, які допомогли 6 йому «адекватно вербалізувати актуальний для нього зміст» (Спільник, 2004: 109). Інакше кажучи, автор висловлення використовує сполучники з компонентами не те що, не те щоб тоді, коли він «не має такого вербального відображення ситуації, яке б він оцінював як достатнє, тобто такого, що відповідає зображуваному явищу та комунікативному наміру» (Ломакович, \& Шмельова, 1985: 120). Отже, використовуючи сполучники з компонентами не те що, не те щоб, автор висловлення добирає ту назву, яка, на його думку, найбільш точно відображала б ситуацію реальної дійсності й була б достатньою для реалізації його комунікативної мети. 


\section{Висновки}

Отже, аналіз досліджуваного матеріалу дає змогу стверджувати, що в українській мові функціюють два парні сполучники з компонентами не те щьо, не те щоб. 3-поміж інших градаційних парних сполучників вони вирізняються тим, що їхні обидві частини можуть варіюватися. Морфологічними варіантами першої частини сполучників з компонентами не те що й не те щоб можуть виступати форми не то щь, не то щоб, не так що, не так щзоб. Варіативність другої частини цих сполучників полягає в тому, що вона може бути представлена компонентами $a$, але, $a \breve{u}$, але $\breve{u}$, проте, та. У другій частині речень разом з компонентом $a$, інколи й замість нього можуть бути використані лексеми просто, навіть, навпаки, тільки, взагалі, скоріше, сам (сама, самі), все ж, якось, вже, бодай, хай, що не входять до складу сполучника. Крім того, друга частина цих сполучників може не вживатися. Незалежно від того, у якому порядку розміщені частини простих градаційних речень, прямому чи зворотному, критерію необхідності завжди відповідає зміст тієї частини речення, яка мітить компоненти не те що, не те щоб, а зміст іншої - критерію достатності, що дають змогу схарактеризувати сутність градаційного відношення.

Перспективою подальших розвідок може стати виявлення особливостей лексико-семантичного наповнення частин градаційних речень, поєднаних сполучниками з базовими компонентами не те що, не те щьоб.

\section{ЛIТЕРАТУРА}

1. Весельська, Г. (2010). Нові явища у функціонуванні градаційних сполучників. Мовознавчий вісник, 11, 165-168. 2. Весельська, Г. С. (2014). Нові явищза у функціонуванні сурядних сполучників в украйнській мові кіния XX-початку XXI cm. Житомир: Вид-во ЖДУ. 3. Городенська, К. Г. (2019). Градаційні складносурядні речення в українській мові: структура та внутрішньозначеннєва диференціація. Украӥнська мова, 3 (71), 29-39. 4. Завальнюк, І. Я. (2009). Оновлена стилістична конотативність складносурядних речень в українському газетному мовленні початку XXI ст. Наук. часопис Наи. пед. ун-ту імені М. П. Драгоманова. Серія 10 «Проблеми граматики і лексикології української мови», 5, 200-205. 5. Караман, С. О. (Ред.) (2011). Сучасна українська літературна мова. Київ: Літера ЛТД. 6. Ломакович, С. В., \& Шмелёва, Т. В. (1985). Выражение номинативных затруднений говорящего (в простом и сложном предложении). Синтаксические связи, строение формантов и семантические отночения в сложном предложении (с. 119-128). Калинин: КГУ. 7. Пономарів, О. Д. (Ред.) (1997). Сучасна украӥнська мова. Київ: Либідь. 8. Рула, Н. В. (2018). Градаційні речення як семантико-синтаксичний різновид складносурядних конструкцій. Південний архів. 
Серія «Філологічні науки», 72 (Т. 1), 31-34. 9. Слинько, І. І., Гуйванюк, Н. В., \& Кобилянська, М. Ф. (1994). Синтаксис сучасної української мови: проблемні питання: навч. посіб. Київ: Вища шк. 10. Спільник, Т. М. (2004). Градаційне відношення в структурі складних сполучникових конструкцій сучасної української мови. (Дис. ... канд. філол. наук). Харків: ХДПУ імені Г. С. Сковороди.

\section{REFERENCES}

1. Veselska, H. (2010). Novi yavyshcha u funktsionuvanni hradatsiinykh spoluchnykiv [New phenomena in functioning of gradation conjunctions]. Movoznavchyi visnyk - Linguistic Bulletin, 11, 165-168 [in Ukrainian]. 2. Veselska, H. S. (2014). Novi yavyshcha u funktsionuvanni suriadnykh spoluchnykiv $v$ ukrainskii movi kintsia XX - pochatku $X X I$ st. [New phenomena in functioning coordinate conjunctions in the Ukrainian language of the late XX - early XXI century]. Zhytomyr: Vyd-vo ZhDU [in Ukrainian]. 3. Horodenska, K. H. (2019). Hradatsiini skladnosuriadni rechennia v ukrainskii movi: struktura ta vnutrishnoznachennieva dyferentsiatsiia [Gradation compound sentences in the Ukrainian language: structure and intra-semantic differentiation]. Ukrainska mova - Ukrainian language, 3 (71), 29-39 [in Ukrainian]. 4. Zavalniuk, I. Ya. (2009). Onovlena stylistychna konotatyvnist skladnosuriadnykh rechen $\mathrm{v}$ ukrainskomu hazetnomu movlenni pochatku XXI st. [Updated stylistic connotation of compound sentences in Ukrainian newspaper broadcasting of the beginning of the XXI century] Nauk. chasopys Nats. ped. un-tu imeni M. P. Drahomanova - Scientific journal of the M. P. Drahomanov National Pedagogical University. Seriia 10 «Problemy hramatyky i leksykolohii ukrainskoi movy», 5, 200-205 [in Ukrainian]. 5. Karaman, S. O. (Red.) (2011). Suchasna ukrainska literaturna mova - Modern Ukrainian literary language. Kyiv: Litera LTD [in Ukrainian]. 6. Lomakovich, S. V., \& Shmelyova, T. V. (1985). Vyrazhenie nominativnyx zatrudnenij govoryashhego (v prostom i slozhnom predlozhenii) [Expression of the speaker's nominative difficulty (in a simple and complex sentence)]. Sintaksicheskie svyazi, stroenie formantov $i$ semanticheskie otnosheniya $v$ slozhnom predlozhenii - Syntactic connections, structure of formants and semantic relations in a complex sentence (pp. 119-128). Kalinin: KGU [in Russian]. 7. Ponomariv, O. D. (Red.) (1997). Suchasna ukrainska mova - Modern Ukrainian language. Kyiv: Lybid [in Ukrainian]. 8. Rula, N. V. (2018). Hradatsiini rechennia yak semantyko-syntaksychnyi riznovyd skladnosuriadnykh konstruktsii [Gradation sentences as a semantic-syntactic kind of compound constructions]. Pivdennyi arkhiv - Southern archive. Seriia «Filolohichni nauky», 72 (T. 1), 31-34 [in Ukrainian]. 9. Slynko, I. I., Huivaniuk, N. V., \& Kobylianska, M. F. (1994). Syntaksys suchasnoi ukrainskoi movy: problemni pytannia - Syntax of the modern Ukrainian language: problematic issues. Kyiv: Vyshcha shk. [in Ukrainian]. 10. Spilnyk, T. M. (2004). Hradatsiine vidnoshennia v strukturi skladnykh spoluchnykovykh konstruktsii suchasnoi ukrainskoi movy [Gradation relation in the structure of compound conjunction constructions of the modern Ukrainian language]. Candidate's thesis. Kharkiv: KhDPU imeni H. S. Skovorody [in Ukrainian].

Спільник Тетяна Миколаӥвна - кандидат філологічних наук, доцент, доцент кафедри філології, перекладу та стратегічних комунікацій, Національна академія Національної гвардії України; майдан Захисників України, 3, м. Харків, 61000, Україна. 
Tel.: +38-050-95-26-758

E-mail: rosinka725@gmail.com

http://orcid.org/ 0000-0002-1913-010X

Spilnyk Tetiana Mykolaivna - Candidate of Philological Sciences (Ph.D.), Docent, Associate Professor at the Department of Philology, Translation and Strategic Communication, National Academy of the National Guard of Ukraine; 3 Zakhysnykiv Ukrainy square, Kharkiv, 61000, Ukraine.

Надійшла до редакції 22 лютого 2021 року

\section{CITATION}

ДСТУ 8302:2015: Спільник Т. М. Специфіка функціювання градаційних сполучників з компонентами не те що, не те щоб. Лінгвістичні дослідження: зб. наук. пр. Харк. нац. пед. ун-ту імені Г. С. Сковороди. Харків, 2021. Вип. 54. Ч. І. С. 50-59. DOI: https://doi.org/10.34142/23127546.2021.54.1.05

APA: Спільник, Т. М. (2021). Специфіка функціювання градаційних сполучників з компонентами не те що, не те щоб. Лінгвістичні дослідження, 54 (I), 50-59. DOI: https://doi.org/10.34142/23127546.2021.54.1.05 